\title{
RETRACTED: PIERCED SALT DOMES IN THE PERSIAN GULF AND IN THE ZAGROS MOUNTAIN RANGES IN SOUTHERN IRAN AND THEIR RELATIONSHIP TO HYDROCARBON AND BASEMENT TECTONICS
}

\author{
Hamid Reza Samadi ${ }^{1}$ \\ ${ }^{'}$ Member of Young Researchers Club, Ardestan Branch, Islamic Azad University, Ardestan, Iran
}

\begin{abstract}
The most enigmatic problems with the nearly 200 salt domes pierced in the Persian Gulf and in the Zagros Mountain Ranges (ZMR) in southern Iran, a unique morphology in the world, have been the matter of this study, which is based on a combination of field work, enhancement of satellite and aerial photographs etc. In the ZMR, structural anomalies are frequently associated with similar facies distribution patterns. In the eastern portion of the region, emergent salt plugs of Infra-Cambrian age exhibit the same alignment patterns. Such trends bear no apparent genetic relationship to the Tertiary folding responsible for the present Zagros fold belt, but rather indicate their affinity with linear basement features which are readily observable on Land sat imagery and aerial photographs. Bending of anticlines in the competent cover rock, combined with minor strike-slip faults and horizontal displacements of parts of folded structures, strongly point to the presence of these basement faults. The salt plugs, which have pierced cover rocks of up to $10000 \mathrm{~m}$ thick, are distributed on the Arabian Platform along regional basement faults. The area of diapir outcrops is bounded by the Oman Line to the east and by the Kazerun fault to the west. Pieces of the basement have been brought up to the surface on some of the salt domes. The fragments were transported by rotational ascent of the Hormuz Salt Formation to the present and former land surfaces. The recognition of features related to basement tectonics and realization of their implication in the control and modification of geological processes are important adjuncts to the search for hydrocarbon accumulations in this region. To our best knowledge, data of basement faults in the study area are scarce. Therefore, this study was carried out to determine basement faults and their relation to salt dome distribution. Considering the fold axes bending, the trend of the salt plugs and also the distribution of epicenters of the last century, numerous new basement faults are introduced in this paper.
\end{abstract}

Keywords: Pierced, Salt plugs, Zagros Fold belt, Southeastern Iran, Kazerun fault.

Received: 24 October 2013/ Revised: 11 November 2013/ Accepted: 15 November 2013/ Published: 18 November 2013

\section{INTRODUCTION}

Although the salt domes in southern Iran, especially those around Bandar-Abbas, which geologically could be called "salt dome province", have been a matter of investigation resulting in numerous publications since 1908, this paper has the following innovations:

- There have been vague ideas that salt domes are outcropped along basement faults. This is true, but this paper explains why they are not linear, but equidimensional. Most of the basement faults presented in this paper have been mapped for the first time.

- This paper uses the accurate location of all earthquake epicenters of the complete last century until 2008 to find their relation to the basement faults. 
Moreover, this paper explains the relation between some basement faults and the bending of the folds. Photo- geological and satellite imagery studies of the ZMR have led to the recognition of lineament pattern. These linear features persist with constant alignments throughout the region. In common with findings from other areas worldwide, the pattern of surface lineaments is considered to be related to basement structure (Goudie, 1989). The present surface manifestations of basement discontinuities can also be related to structural and stratigraphic patterns and anomalies. The emplacement pattern of emergent salt domes in the ZMR is related to basement structures.

\section{GEOGRAPHICAL AND CLIMATE SITUATION}

The studied area lies in the southern part of Iran near the northern shore of the Persian Gulf and is limited by coordinates: $26^{\mathrm{o}} 30^{\prime}-28^{\mathrm{O}} 15^{\prime} \mathrm{N}$ and $53^{\mathrm{o}} 30^{\prime}-56^{\mathrm{O}} 30$ (Fig. 1).

The southeastern part of the area belongs mostly to the Hormozgan Province, and the northwestern part of the area to the Fars Province, the district of Bandar Abbas, Lar, and Jahrom. The area belongs to an arid type of climate (hot and dry), locally modified by the mountains (lower temperature, higher rainfall) and by the Persian Gulf (higher air humidity, hot summers). Annual average precipitation varies from 50 to $350 \mathrm{~mm}$. There are places in some mountain ranges with more than $600 \mathrm{~mm}$. The relative air humidity varies from 26 to $98 \%$. The average annual temperature is about $27^{\circ} \mathrm{C}$. The warmest months are July and August (about $36^{\circ} \mathrm{C}$ ). In the arid climate of Iran, the salt can break through to the surface and flow on a salt glacier down the flanks of the dome. When moistened with groundwater or precipitation, salt flows even more rapidly. Extruded salt at the heads of some Iranian salt glaciers flows at a rate of $2 \mathrm{~m} / \mathrm{yr}$ (Jackson and Talbot, 1986; Talbot and Alavi, 1996).

\section{REVIEW OF PREVIOUS INVESTIGATIONS}

The inland exposure of the Hormuz Series was first described by (Pilgrim, 1908; 1922; 1924) and Busk and Mayu (1918). The works of (Richardson, 1926; 1928) and (Lees, 1927) marked the beginnings of modern studies of the Hormuz salt plugs, and subsequently 63 of them were mapped and described briefly by Böckh et al. (1929). The first systematic study of these plugs was Harrison's great contribution, the results of which were published in 1930, 1931, and 1956. Kent (1958) investigated nine plugs and later published the results of some of the most recent work on the south. These two articles are particularly significant, as they contain new information on the age of the salt and the structural setting of the plugs in relation to regional tectonics in the Persian Gulf basin. Useful contributions were made by Gansser (1960) and Ala (1974), who reviewed the geology of salt domes in various parts of Iran, including the Persian Gulf, and summarized the current ideas of their origin. Player (1969), Stöcklin and Nabavi (1975), Farhoudi (1978), who explained why the Hormuz Formation appears to be multilayered, Talbot and Rogers (1980), Farhoudi (1984), Farhoudi and Ghazizadeh (1993),Bosak et al. (1998),Farhoudi et al. (2008),Rahnama-Rad et al. (2008), also published some of the most recent works on the southern Iranian salt dome province.

\section{GEOLOGICAL SETTING}

The ZMR in southern Iran, located on the Iranian side of the Arabian Platform, is a branch of the Alpine- Himalayan orogenic belt (Fig. 2). The northwest- southeast structural trend of the ZMR resulted from compressive folding during Upper Pliocene time. This Alpine orogenic grain masks and modifies earlier patterns of structural deformation (McQuillan, 1991). Three structural belts with intensity of deformation increasing in a northeasterly direction have been defined (Falcon, 1967; 1969). The simply folded belt lies to the southwest and passes over into the imbricated belt in the high Zagros, while further to the northeast the crush zone is coincident with the suture zone of Haynes and McQuillan (1974). The stratigraphy and sedimentology of the ZMR have been described by James and Wynd (1965),by Falcon (1974),andFarhoudi (1978). The Phanerozoic column is about $12000 \mathrm{~m}$ thick. Paleozoic sedimentation was mainly epicontinental; from Permian to Miocene time it consisted chiefly of carbonates. The Tethys Ocean began to subduct under the Iranian plate in the Late 
Cretaceous. Cessation or slow subduction resulted in carbonate sedimentation in Early Cenozoic time (Ross et al., 1973; Farhoudi, 1978) as well as the deposition of $400 \mathrm{~m}$ evaporitic materials in the Miocene. Orogenic movements began in the Middle or Upper Miocene when sedimentation became clastic. The opening of the Red Sea intensified folding and uplifting of the ZMR, which are still going on. Most of the salt diapers are located in Hormozgan and the southeastern part of Fars Provinces (Fig. 2). The diapir field is bounded by the Oman Line to the east, the Kazerun fault to the west, and the Main Zagros Thrust to the north (Fig.1), (Derakhshani and Farhoudi, 2005). Only a few salt diapers reach the surface northwest of the Kazerun fault near the Main Zagros Thrust. They occur in great number also in the form of small islands in the Persian Gulf, south of the boundary of the Zagros Folded Belt (Ala, 1974). The presence of numerous salt domes, mainly of the Hormuz Formation, indicates tectonic activity of the ZMR. Although salt domes have been reported in many places of the world (Belderson et al., 1978; Rabinowitz et al., 1982; Schoenherr et al., 2007), e.g. to the north of the Gulf of Mexico in the USA (Seni and Jackson, 1983a; 1983b) and in the northern part of Germany (Trusheim, 1960), most of them are not outcropped and have been detected by geophysical methods. In contrast to them, salt domes in the ZMR and in the Persian Gulf are not only high elevated domes, but also in many cases the salt is flowing down the flanks (Fig. 3) as "salt glacier"

(Talbot and Rogers, 1980; Talbot and Jackson, 1987).

Some of the salt domes are more than $1000 \mathrm{~m}$ higher than the surrounding area, e.g. Kangan salt dome. Some of them have been used as open cast mines.

Fig-1. The studied area belongs mostly to the Hormozgan province, and the northwestern part of the area to the Fars province, the district of Bandar Abbas, Lar, and Jahrom. The diapir field is bounded by the Oman line to the east, the Kazerun fault to the west, and the Main Zagros Thrust to the north. There is no salt dome NW of the Kazerun fault. There are only three salty springs with basement rocks around, which have been dragged from the east by the strike-slip faults.

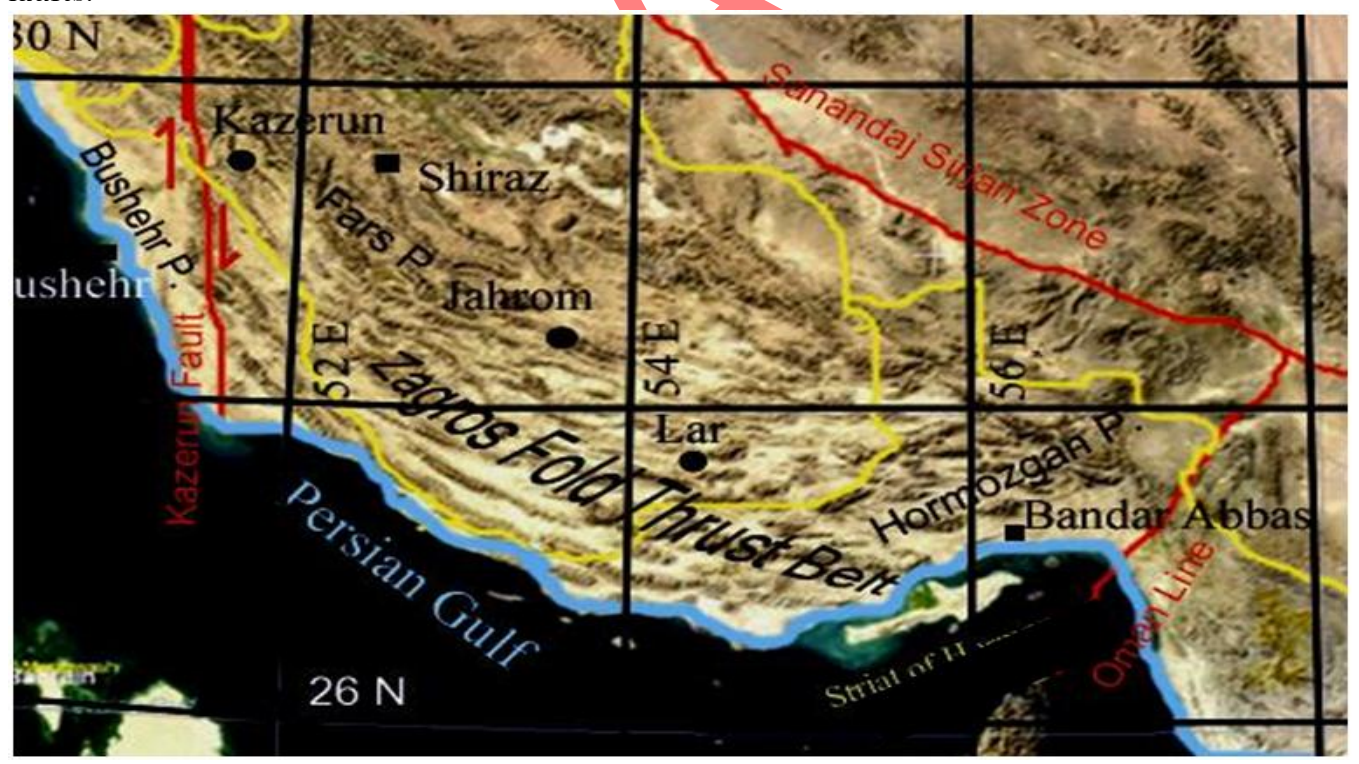

Fig-2. The ZMR, located mainly on the Iranian side of the Arabian Platform, are a branch of the Alpine-Himalayan orogenic belt. The northwest-southeast structural trend of the ZMR resulted from compressive folding due to the opening of the Red Sea during Upper Pliocene time. 


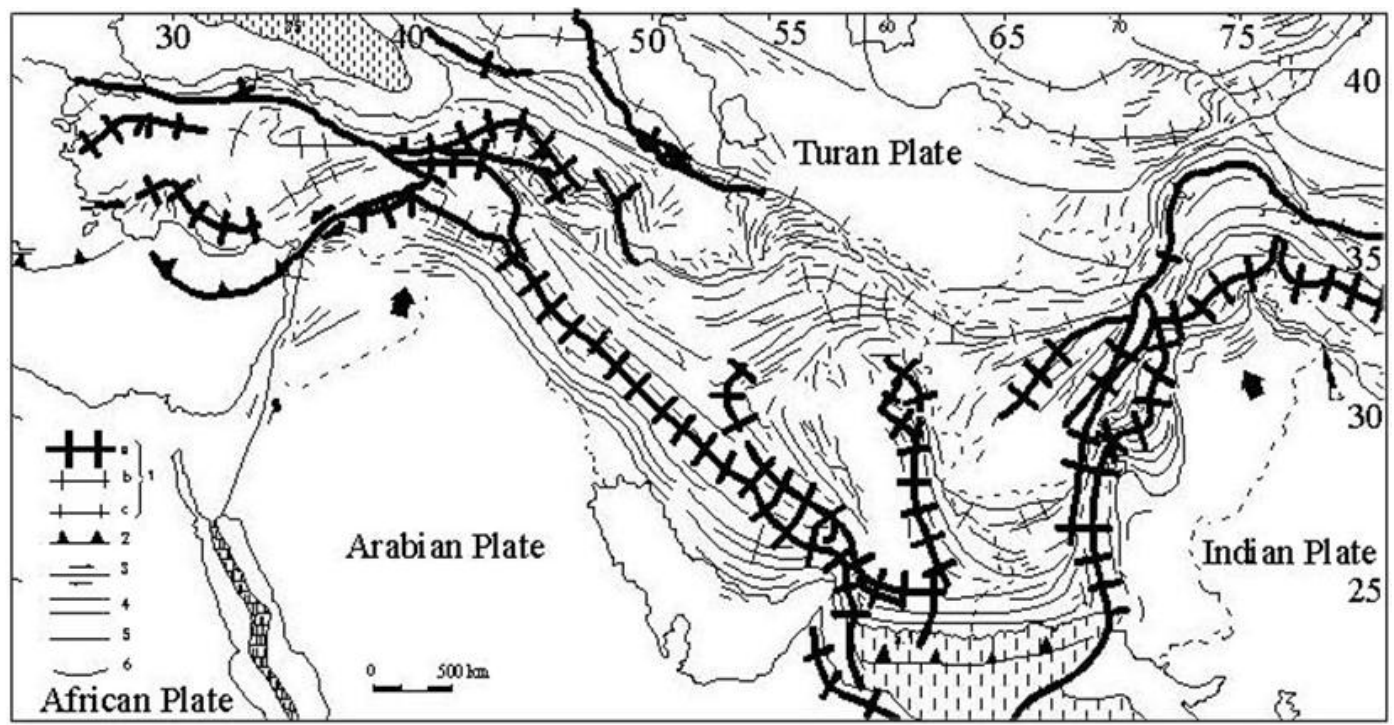

Fig-3. Salt domes in the ZMR and in the Persian Gulf are not only high elevated domes, but also in many cases the salt is flowing down the flanks as "salt glacier". A: Do-Aby salt plug, B: Sketch of the salt plug. The length of plug: $11670 \mathrm{~m}$, with a width of $5970 \mathrm{~m}$.

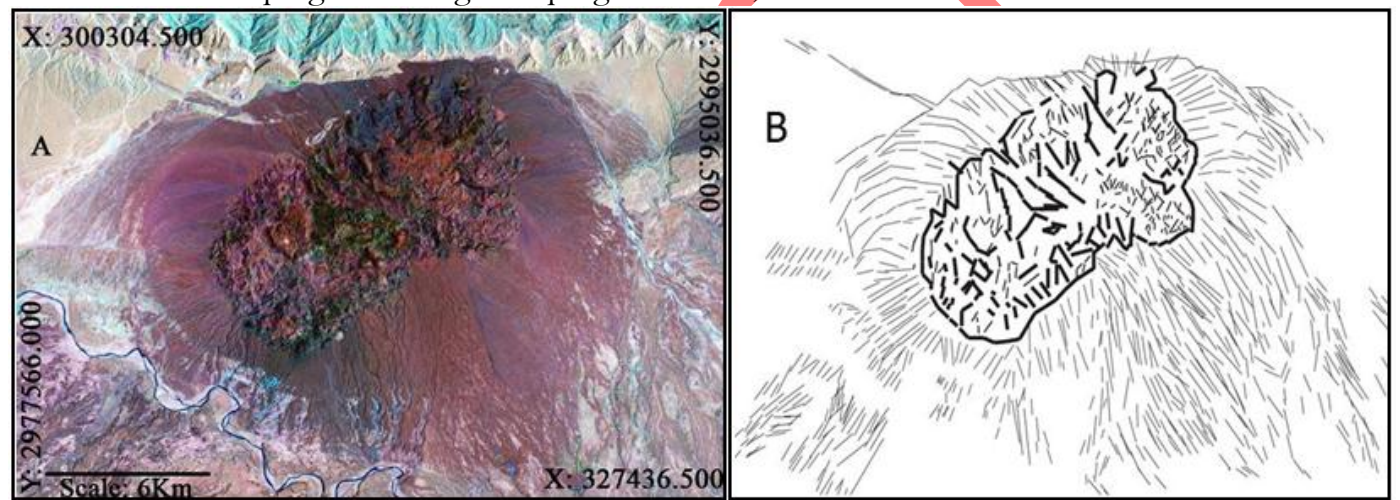

The salt is more soluble than limestone and in contrast to the latter; it has plastic behavior and impedes the flow of fluids. The Tertiary Gachsaran Formation, consisting mainly of salt, anhydrite and marl layers, acts as one of the best cap rocks of hydrocarbon in the Middle East. The ZMR structurally consist of numerous, mostly northwest trending, synclines and anticlines. Steep flanks on most individual structures face southwest (Falcon, 1969). Dextral displacements have been reported on faults parallel to the Main Zagros Thrust between $33^{\mathrm{O}}-35^{\mathrm{O}} \mathrm{N}$ (Tchalenko and Braud, 1974) and also on the Kazerun fault (Falcon, 1974). The near- basement salts play a major role in the morphology and structure of the Zagros Thrust and Fold Belt. These salts cause disharmonic folding and do not permit sub- salt structures to continue upward.

\section{REMOTE SENSING AND PHOTOGEOLOGY}

The interpretation of satellite images based on photogeology of air photos shows several basic trends: NNW-SSE to N-S, passing to NW-SE direction, NNE- SSW, NW-SE, NE-SW and W-E (Fig. 4). The interpretation shows, that some structures have a character of regional photolineaments (especially NNW-SSE and NE-SW trending. Such structures were supposed to be main fault systems of the region. Such structures commonly form broad zones of densely packed lineations. They often have a character of dextral and sinistral strike-slip faults with some normal component. More or less, they represent, at least partly, basement structure projected through the complete pile of the platform cover. Our interpretation differs, on some 
shear zones, in the deduction of the sense of lateral movement. Some photostructures sometimes pass into proved thrust zones, e.g., in the zone between Chahar Birkeh and Champeh plugs (Bosak et al., 1998).

As photolineations often dissect salt plugs, even those most active and/or with extensive young glaciers (Fig.5), it can be deducted that the tectonic activity of the region is also very young, and that fracture-fault zonesrepresent important guides to plug intrusions (Friedrichs and Perry, 2001; Lawrence et al., 2004). Qeshm Island is the largest shore Island near the coast of the Persian Gulf. The smaller offshore islands (Hormus, Larak, Hengam, etc.) are salt plugs (Fig. 6), partly fringed by the recent or subrecent coral reefs.

The continental region can be classified as hilly to mountainous. In general, the W-E trending anticlinal mountain ridges and synclinal valleys are the most distinct morphological elements. In detail, the WNW directions prevail in the western part of the studied area and the $\mathrm{W}-\mathrm{E}$ to NNW ones are more common in the eastern part of the region, including the Qeshm Island. The synclinal depressions show variable morphology. Deep antecedent valleys, common in higher zones of the Zagros Mountains are relatively rare. The feet of ranges are often contoured by telescoping alluvial fans. The geological structure, lithology and tectonics strongly control landscape morphology (Bosak et al., 1998).

\section{FAULTS}

Numerous salt plugs are associated with large fault structures, and, on the other hand, these fault lines of the basement are important for the origin of salt diapirs (Humphrey, 1958). The role of salt for the evolution of thrusts was described by Falcon (1969). Some subordinate thrust faults have developed from simple folds (Kashfi, 1976). Small thrust faults could also be associated with the development of large recumbent folds in the Gachsaran Formation. In the studied area 29 normal and strike slip faults have been recognized (Fig. 7). Some of these faults could have an important role for salt uplifting. The 29 Faults are as follows:

Fault No. 1: This strike-slip fault with $167^{\circ}$ azimuth crosses Chiru salt plug and deviates the axes of some anticlines such as Chiru, Larestan, Gavbast (also, there is about $10 \mathrm{~km}$ right lateral offset in this anticline axis) and Bavash. Also, there are some minor faults parallel to the major fault which is formed as the result of this fault activity. These minor faults specially could be seen in the Larestan, Gavbast and Bayash antichnes. Existence of erosion and collapse structures parallel to this fault trend, in Gavbast and Bavash anticlines could be related to this fault activity too. Minor fault trends and the pattern of erosion in Gavbast anticline increase the possibility of a hidden salt plug in this area.

Fault No. 2: This fault with $148^{\circ}$ azimuth crosses the west of Namaki salt plug in Gavbast anticline and perform a major role by dextral displaced offset of the anticlinal axis. This is may be a minor fault of the fault number 1 , because it has approximately the same direction.

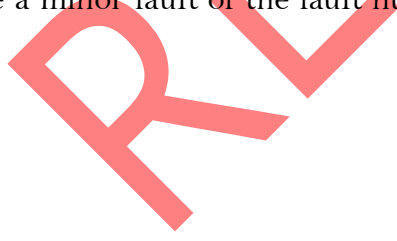


Fig-4. Sketch of several basic trends: - NNW-SSE to N-S, passing to NW-SE direction, NNESSW, NW-SE, NE-SW and W-E.

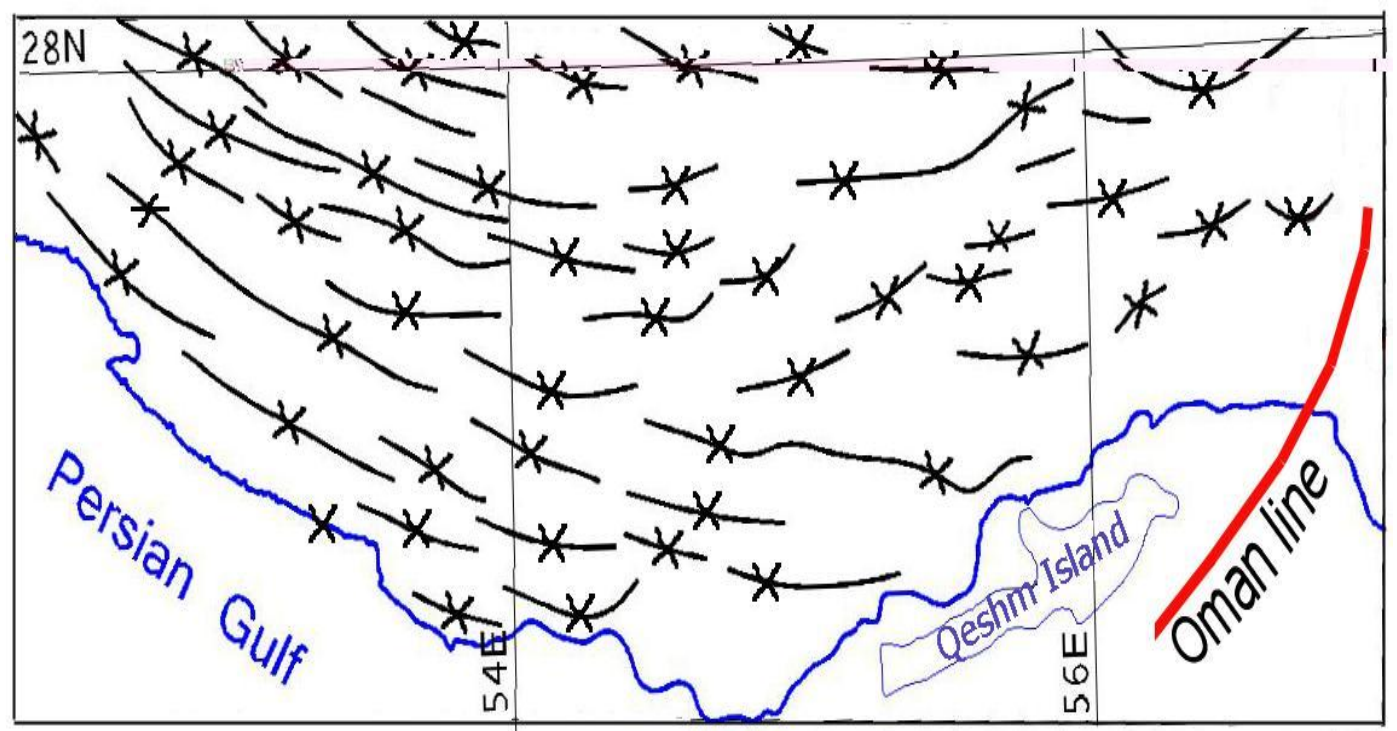

Fig-5. Most active and/or with extensive young glaciers, it can be deducted that the tectonic activity of region is also ver y young, and that fracture-fault zones represent an important guide of plug intrusions. A: Chah-Musallem salt plug, B: Sketch of the salt plug.

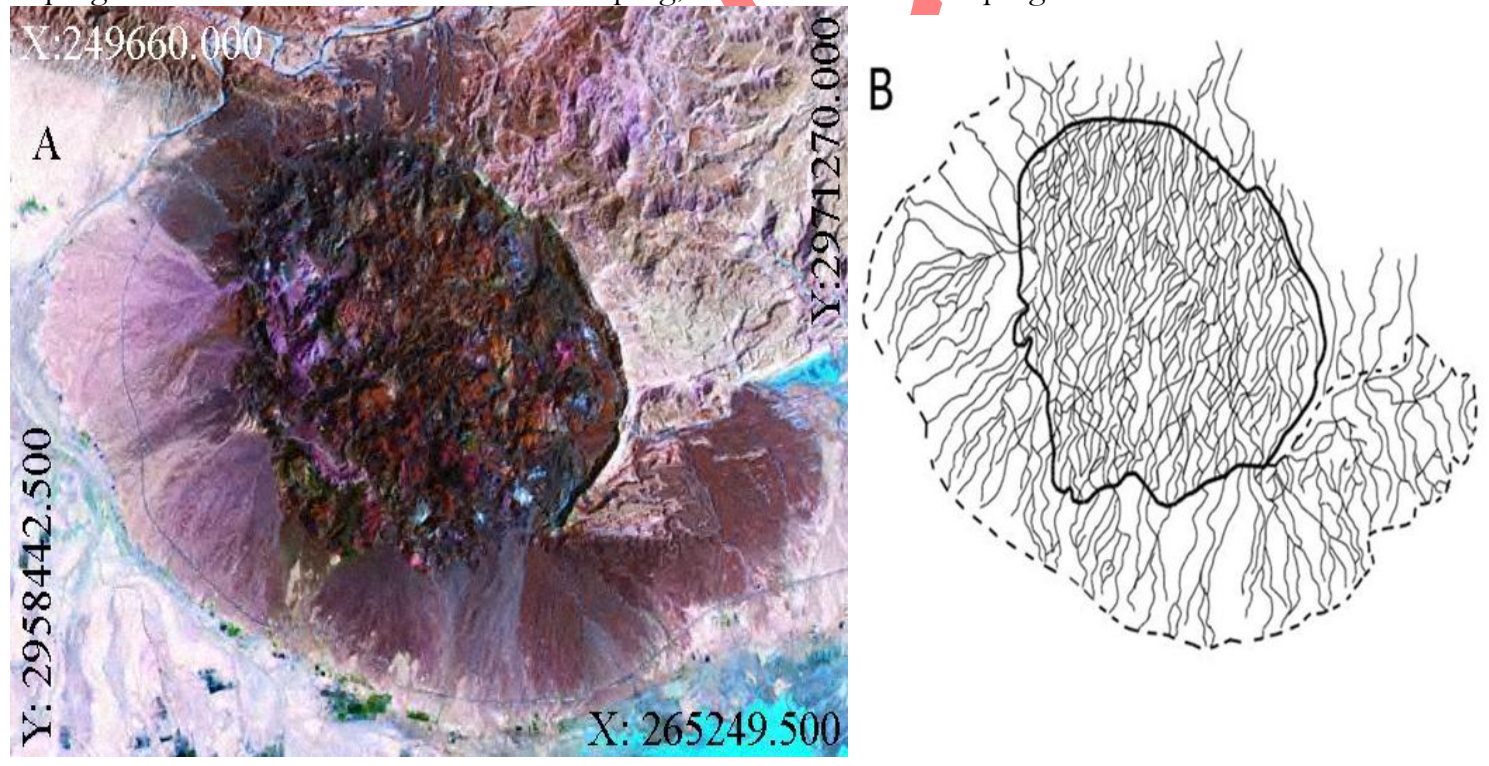

Fault No. 3: This sinistral strike slip fault with $118^{\mathrm{O}}$ crosses from the west end of Nakh anticline, cut off the Aghajari and the Bakhtiari Formation in syncline of the western Bastak and causes numerous minor faults parallel to the major fault and the sinistral deviation of the Gavbast anticline axes. It has probably fulfilled a major role in the hidden creation of Gavbast salt plug.

Fault No. 4: The dextral strike-slip fault with $165^{\circ}$ azimuth caused a dextral deviation of the Gavbast anticline axes (eastern end), a noticeable displacement of Nakh anticline axes and its syncline axes. This is well distinct especially in the NW crest of Nakh anticline (Asmari-Jahrom, Gachsaran and Gurpi outcrops of salt plugs located in the eastern and northeastern on the Bastak could not be irrelevant to the fault function. The fault continuation in the southeastern caused the deviation of the Herang and Namak anticline axis and passes from the Namaki salt 
plug at the western end of the Champeh anticline.

Fault No. 5: The strike-slip fault with $140^{\circ}$ azimuth caused deviation and dextral displacement of the Bustaneh, Champeh, Herang, Nakh, Gavbast and Paskhand anticlinal axes. Along the continuation of this fault there are other salt plugs, among them the Kildun salt plug terminated by a fault which cuts the Aghajari and Bakhtiari Formations, produces steep scarps and is parallel to the fault No 5 .

Fault No. 6: The dextral strike-slip fault with $135^{\circ}$ azimuth has caused right lateral offset of the axes of some anticlines such as Kuh-e Kohneh, Pishavar, Gach, Burkh, Nakh and Champeh. There are seven salt plugs, such as Kermostaj in Gach anticline, Bam and Namakdan in Qeshm Island, which are outcropped in the direction of this fault. To the southeast, this fault may cross Tonbe Bozorg salt plug. In Kohneh anticline, it creates some minor faults parallel to itself and some of them to the axis of Kohneh anticline. Because of the activity of the minor faults, recognition of the anticlinal axis is very hard at this part of the anticline. This fault has created some minor faults parallel to itself by crossing Nakh anticline.

Fault No. 7: The fault has a $135^{\circ}$ azimuth crossed the Bundasht anticline and a salt plug located in south of the Bundasht anticline and caused the brief deviation in anticline axis. Probably it fulfills a major role in creating a pull-apart basin.

Fault No. 8: The dextral strike-slip fault with $135^{\circ}$ azimuth has caused deviation of the Bundasht, Shamilu and Shab anticline axes. There are two salt plugs in the trend of this fault. The thrust faults located in Bundasht anticline may be the product of this fault. Fault No. 8 accompanying fault No.7 probably has caused the pull- apart basin and the outcrop of the salt plug.

Fault No. 9: The strike-slip fault with $139^{\circ}$ azimuth has caused the sinistral deviation of the Khamir anticline axis. The trend of the Kurzien anticline and the deviation of the Suza anticline axis (located in Qeshm Island) can be considered as this fault's function. The Hengam salt plug has been outcropped in this fault direction.

Fault No. 10: The fault with $136^{\mathrm{O}}$ azimuth causes sinistral deviation of the anticlinal axes of Gachin,

Gismo, Guniez and Muran. In the fault continuation

outcropped four salt plugs, such as Anguran salt plug and in the Guniez anticlinal direction there are some minor faults.

Fault No. 11: The strike-slip fault with $133^{\circ}$ azimuth caused sinistral deviation of the Gachin and Holure

anticlinal axes and the eastern end of the Suza

anticline. Furthermore, the minor fault creation in the Suza anticline, along with the major fault, is probably a function of the fault No.11.

Fault No. 12: The fault with $139^{\circ}$ azimuth caused the sinistral deviation of the Muran, Finu, Handun and

Namak anticlinal axes. The rotation of the Muran

anticline is a remarkable phenomenon which is occurred in consequence of the fault function. There are many outcrops of salt plugs along the major fault, among others Handun and Namak salt plugs.

Fault No. 13: The anticline axes of Genu and Gachin are deviated dextral in consequence of the fault function. The Genu, Namak and Hormuz salt plugs are placed on the fault azimuth with $153^{\mathrm{O}}$.

Fault No. 14: The strike- slip fault with $147^{\circ}$ azimuth caused the dextral deviation of the anticlinal axes of

Furgun, Neyze and Koshku. The existence of serious

displacements in the direction of the fault and the linear outcropping of the hidden plugs in a line form (especially in Koshku) along the major fault are characteristic. 
Fault No. 15: The strike slip fault with $147^{\mathrm{O}}$ azimuth caused the sinistral deviation of the Kushkuh anticlinal

axis.

Fault No. 16: The strike-slip fault has a $71^{\circ}$ azimuth. The shape of the syncline located between the Handun, Namak, Neyze, Kushkuh and Forgun anticlines is affected by the dextral fault activities.

Fault No. 17: The dextral deviations of the Forgun, Neyze, Namak, Genu, Gachin and Kurzien anticlinal axes are the results of activities of a strike-slip fault with $41^{\mathrm{O}}$ azimuth. Along this faults are many salt plugs such as Gachin, and Namak salt plugs. The fault has caused numerous minor faults in the Kurzien anticline.

Fault No. 18: The deviation of the Handun, Genu, Gashu, Kurzien anticlinal axes and of the west end of the Suza anticline are the results of the dextral activities of a strikeslip fault with $18^{\mathrm{O}}$ azimuth. The Gachin salt plug is an outcropped plug in the fault direction. The existence of a few minor faults especially in the Suza anticline is probably due to the activities of this fault.

Fault No. 19: The Naghshe and the Salakh anticlinal axes and the eastern end of Khamir anticline have been deviated due to the dextral activity of a fault with $13^{\circ}$ azimuth. Also the scarp of the Aghajari Formation in Gachin anticline and the $9^{\circ}$ deviation of the river Goal in its course should be regarded as the result of the fault activity. The Poal salt plug has been outcropped parallel to this fault trend.

Fault No. 20: This strike-slip fault with $31^{\circ}$ azimuth has caused a dextral deviation of the Khamir anticlinal axis. There are some active lineations having the same trend with this fault in the southern alluvium fans of the Khamir anticline.

Fault No. 21: This fault with $40^{\circ}$ azimuth has caused sinistral deviation and displacement of the Muran anticlinal axis. Baz and Guniez anticlinal axes have been distorted due to the function of this fault. This fault has also caused the outcrop of four salt plugs in its direction.

Fault No. 22: The sinistral function of this fault with $36^{\circ}$ azimuth, which is concave to the east, has caused the deviation of the Muran, Shab, Ilcheh, Champeh and of the east end of Shemilu anticlines. The creation of minor faults especially in Muran and Ilcheh anticlines is also due to the function of this fault. Several salt plugs, such as Hamiran and Namaki salt plug have been outcropped in the direction of this fault.

Fault No. 23: This fault with $76^{\circ}$ azimuth has caused sinistral deviation of Baz, Shab, Bam, Nakh, Herang, Namak and Chiro anticline axes and in its southwest terminal extends to the Handurabi Island. In this fault trend there are about seven salt plugs, such as Namaki, Bam and Shab salt plug. Several minor faults can be observed in Baz, Shab, Bam and Namak anticlines, which have been created due to the function of this fault. So the fault southeast of Bam is a longitudinal and completely remarkable. The function of this fault in the Shab anticline, not only has caused a $60^{\circ}$ deviation of the anticlinal axis, but it is the reason for the outcrop of a series of outstanding minor faults and the outcropping of the Shab salt plug. An about $2.5 \mathrm{~km}$ sinistral displacement in the Nakh anticlinal axis has been due to the function of this fault. In the fault displacement of the anticlinal axis trend, there are some normal faults shaped like circles which have been oriented in a way that they imply the existence of a hidden salt plug. Fault No. 24: The out crop of six salt plugs with almost equal distance to each other is the outstanding characteristic along this fault. The fault with $76^{\circ}$ azimuth has caused the sinistral displacement of the Bawiun, Champeh and Herang anticlinal axes. The existence of parallel faults with the major faults, especially on the boundary between the Kildun and the Kuhe Kalat Souru salt plugs, is also a part of the strike- slip fault characteristics.

Fault No. 25: This strike-slip fault with $81^{\circ}$ azimuth has caused the sinistral deviation of the Champeh, Ashouro and Boostaneh anticlines as well as interstructural changes. Three salt plugs have appeared along this fault. The existence of the minor faults on the boundary between the salt plugs can also be the reason for the sinistral effect of this fault.

Fault No. 26: This fault with $14^{\circ}$ azimuth and a little concave to the west has caused the 
sinistral displacement and the creation of surface features. This fault starts from the west end of Dasht-e- Kanar anticline in the north and has caused the deviation of Qaleh Shur, Bawiun, Harang, Champeh and Boostaneh anticlinal axes. Seven salt plugs have appeared along this fault. The longitudinal margin of the salt plug located in the east of Harang anticline and the minor fault located in the Bam salt plug are the result of this fault activity. The continuation of this fault could have passed through the minor and major Farur Islands.

Fault No. 27: This strike-slip fault with $57^{\circ}$ azimuth has caused a sinistral deviation of the Harang and Namak anticlinal axes and the east end of the Cheero anticlinal axis. This fault is likely to pass through the east of the Kish Island. Two salt plugs could be outcropped along this fault. This fault is probably a branch of fault No.23.

Fault No. 28: This fault with $50^{\circ}$ azimuth and sinistral displacement starts from the western parts of the Dasht-e-Namak and causes the deviation in the eastern part of the Gach anticline and also the Burkh, eastern end of Gavbast, eastern end of Gazeh, Kooh-Namak and cheeroo anticlinal axes. Seven salt plugs have appeared along this fault.

Fault No. 29: This fault with $67^{\circ}$ azimuth and sinistral displacement starts at the eastern end of Kurdeh anticline and has caused the deviation of the Kurdeh, Gach, western end of Burkh, eastern end of Paskhand, Gavbast and Dehnow anticlinal axes. The longitudinal incision of the eastern Kurdeh anticline and the boundary of the salt plug located in this anticline, detectable detachment and displacement of the Gach anticlinal axes, a completely distinguishable deviation on the boundaries of Paskhand and Burkh anticline and appearance of salt plug in this region and creation of minor faults, especially in the Kurdeh, Gach and Dehnow anticlines and also appearance of six salt plugs on this stretch, are some of the remarkable fault characteristics.

Fig-6. Qeshm Island is the largest shore island near the coast of the Persian Gulf. The smaller offshore islands (Hormuz, Larak, Hengam, Kish-Kuh (in Island, etc.) are salt plugs.

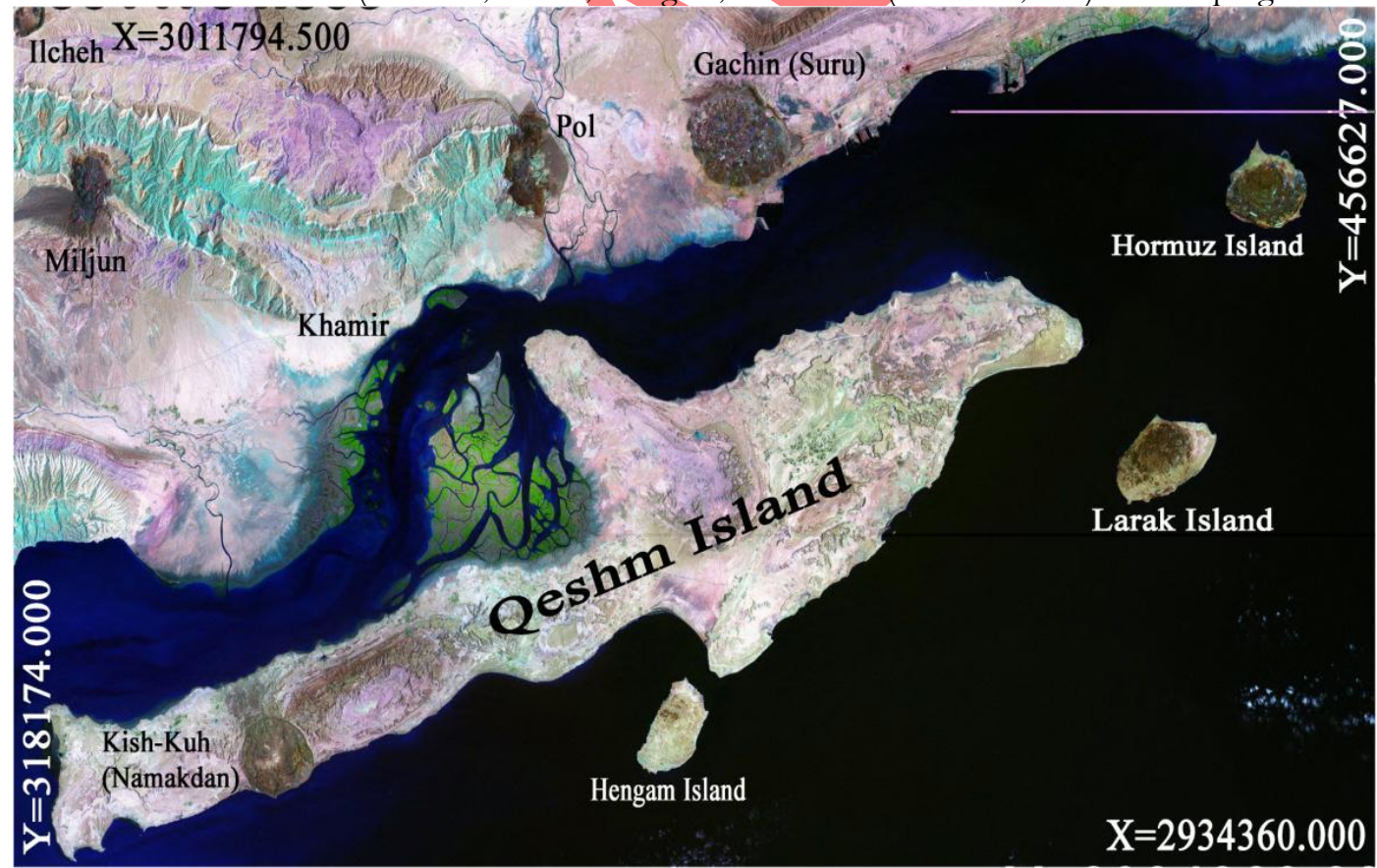

\section{SALT PLUGS AND BASEMENT STRUCTURAL FEATURES (DISCUSSION)}

About two hundred emergent Hormuz salt plugs are known in southwest Iran. Characteristic dome-shaped swellings on elongate surface anticlines (Fig. 8) indicate the presence of many more intrusive salt masses at shallow depths. The majority of these unusual and 
spectacular diapirs are located in Fars Province. Kent (1958), in commenting that the Zagros fold belt owes its "Jura-type" folding mode to a basal plastic or incompetent layer, implies a thick and widespread Hormuz evaporate presence. Investigations to the northeast of the Zagros by Stöcklin (1968) corroborate this concept. Regional location of the plugs shows no relation to Upper Tertiary folding though it is interesting to note that not all, but most, plugs are associated with Zagros fold axes. In some cases active plugs in some positions appear to have previously inflated the anticlines, following on the extrusion of salt from the fold and the collapse folds (Player, 1967). Such structures possibly reflect Bostrom (1985) observations of salt plugs associated with axial fold displacements (Fig. 9).

According to Brink (1986), and Fürst (1990), two strike-slip parallel faults with the same sense of motion are necessary to move the salt, which is located between them, upwards. This is not true; the Kerebas fault (near Shiraz and Arjang plain) alone has brought 5 salt domes to the surface. Talbot and Alavi (1996), believe that through the strike-slip faults the salt is always in a pull-apart basin. This is not true; many salt domes are exactly on the crest of anticlines (Fig. 10). Basement rocks are nowhere exposed in the ZMR. An Infra-Cambrian age has been assigned to evaporate and polygenetic assemblages of rocks which comprise the Hormuz group (Kent, 1979; 1986). These rocks are seen only in small, scattered, emergent plugs associated with thrust faults in the imbricated belt of Khuzestan province and more abundantly throughout Fars province. These large plugs and salt glaciers contain rafts of Cambrian sediments and a mixed assemblage of dominantly intrusive rocks grouped under the general term of greenstones (McQuillan, 1991).Bakhtiari and Aghajari Formations, located on the boundaries of Gavbast and Gazeh anticlines, can be considered a result of these fault activities.

These exotics provide the only indications of possible basement composition. The structure of the basement is conjectural. The pattern of surface lineament is thought to relate to discontinuities in the basement surface.

Studies of landsat images, aerial photographs of the study area, and distribution of earthquake epicenters, combined with field checking have revealed an abundance of surface linear features. These include stream alignments, subtle topographical patterns, tonal variations, faulting and structural modifications, which do not appear to relate to the late Tertiary folding episode.

The major lineaments of the Kazerun Fault and Oman Line form obvious boundaries to distinct structural regimes. An examination of individual folds exhibits the frequent occurrence of marked structural anomalies in the form of abrupt axial bends or transcurrent disruptions. Regionally such anomalies are seen to lie along trends which correspond to one or more of the

major lineament directions. This indicates the ongoing influence of deep- seated basement structural features and their modification of later folding modes. Overthrusts represent displacements of anticlines to the south with approx. W-E trends. Their length, detected within our region, varies from several 10 kilometers in the $\mathrm{S}$ (the southern flank of the Champeh anticline) up to nearly $100 \mathrm{~km}$ in the $\mathrm{N}$.

The first unknown problem of the Hormuz Formation is its age. The estimations are very vague and mainly based on Trilobites brought to the surface by the salt. There are also some basement rocks, which are brought to the surface. This was explained by the fact that the basement has been thrusted down to the axis of the Persian Gulf (Farhoudi, 1978; Kent, 1979). In this way the Hormuz Formation could be younger than the Trilobites (Palaeozoic).

How can the Hormuz salt plug pierce the $10000 \mathrm{~m}$ thickness of cover rocks and come to the surface? If the upper sediments of the lighter salt play a role, there are more than 400 salt domes in the Gulf of Mexico which are covered with $14000 \mathrm{~m}$ sediments and they are not yet raised up. In Iran the direct and indirect convergence are the cause that creates ridge builder salt plugs by the reactivation of the basement faults. If the salt dome comes up from the faults, why are they not linear, but mostly equidimensional (Figures 8, 10)? How can it happen that together with the salt a "well preserved inclusion" with more than 3

$\mathrm{km}$ diameter comes to the surface? The answer of these three questions is that the strike-slip faults cause the spinning of the surroundings rocks. 
In this case the salt moves like a round thread faster and lighter upwards and transports the rocks resting in the interior mass upwards. This actuality has been published partially by Brink (1986)and thereafter by Fürst (1990). It is an error to think that for a rotation of the rock masses, it needs two parallel strike-slip faults, each on either side of the mass. In the Zagros one can show that only such a fault is sufficient to rotate masses. The salt rest not always in pull-apart basins as Talbot and Alavi (1996) believe, it appears often on the crest of anticlines (Fig. $8,9$ and 10$)$.

Fig-7. In the studied area 29 normal and strike slip faults are recognized. Some of these faults could have an important role for salt uplifting. 1) Hormuz, 2) Larak, 3)Hengam, 4) Namakdan, 5) Hamiran, (Berke-e-Suflin), 6) Moallem, 7) Bostaneh, 8) Mughu, 9) Kalat, 10) Gachin (Suru), 11) Pol, 12) Khamir, 13) Miljun, 14) Do-Aby, 15) Zendan, 16) Champeh, 17) Chah Musaleh (Musallem),

18) Charak (Bavardin), 19) Namaki (Darbast), 20) Kalate Bala, 21) Anguru (Gasho), 22) Ilcheh, 23) Herang, 24) Gazeh, 25) Kameshk, 26) Kushk Kuh (Jaghur 1), 27) Khorgo, 28) Ginau, 29) Guniz, 30) Shu, 31) Bam, 32) Zangard, 33) Bastak 1, 34) Bastak 2,

35) Ahmadi, 36)Kajagh, 37) Finu, 38) Handon, 39) Tarbu (Baz), 40) Tashkend, 41) Shamilu, 42) Chah Banu, 43) Shur, 44) Burkh,

45) Gach, 46) Paskhand, 47) Khain, 48) Harmandan, 49) Nesf rah, 50) Muran (Tang-E-Zagh, 51) Palangi, 52) Namak, 53) Kuredeh,

54) Deh-Kuieh, 55) South Parak, 56) Parak, 57) Faraghon, 58) Gahkum-East, 59) Saadat Abad, 60) Gahkum, 61) Muran-W, 62) Qaleh Shur, 63) Goru, 64) Bana Kuh, 65) Bonaruyeh, 66) Jalalabad, 67) Kush-Kuh, 68) Darbast.

Fault and salt plugs

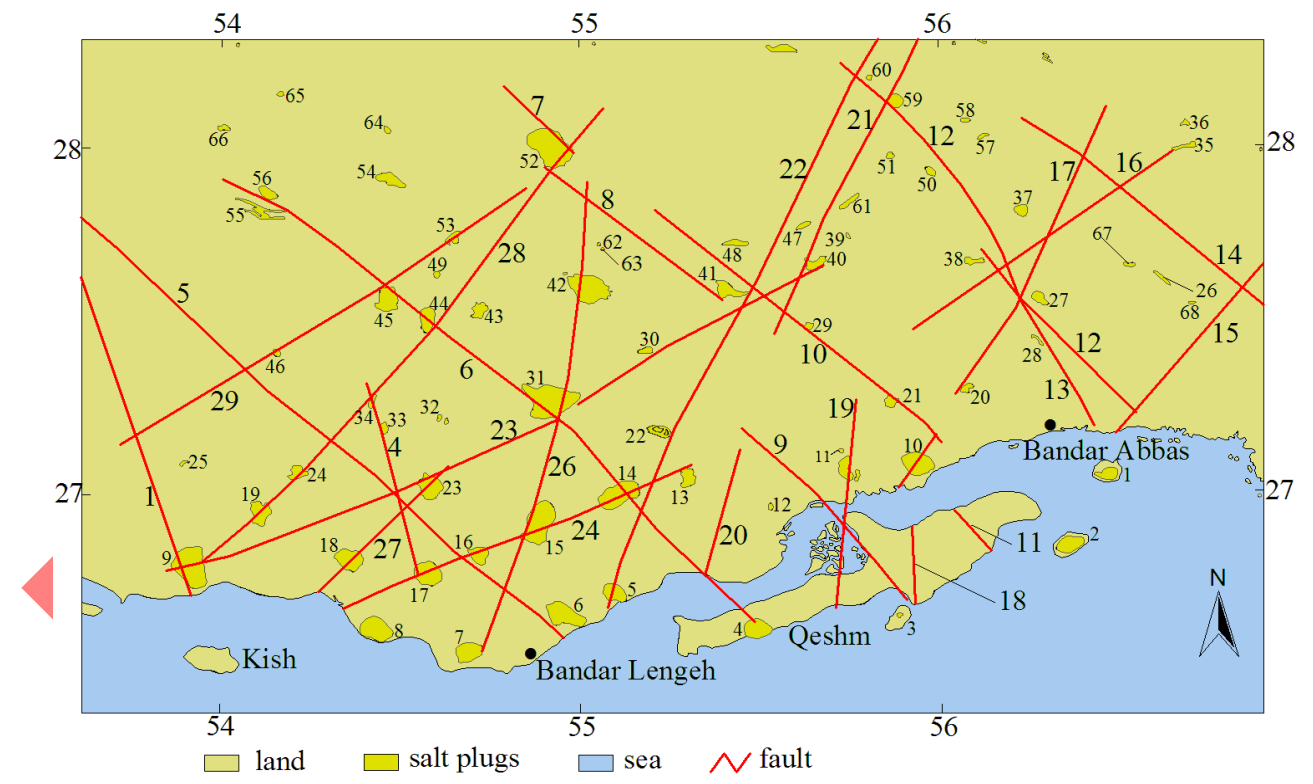

\section{RELATION OF SALT DOMES TO HYDROCARBON}

In order for a salt deposit to move upwards and form a salt dome, we have to have a certain minimum overburden, and the thickness of the salt deposits must be more than about 100-120 m. The movement of salt up through the strata and the deformation of all the sedimentary strata this involves is called halokinetics, or salt tectonics. The movements are very slow, and may continue for several hundred million years. They may lead to the salt breaking through the overlying rocks and flowing up to the surface, or forming intrusions into younger rocks (Figures $3,5,8)$. If the salt contains anhydrite, this mineral will expand and form gypsum when it comes into contact with groundwater as the salt approaches the surface. Traps may be formed in the 
strata above the salt dome, in the top of the salt domes (cap rock), in the strata which curve up against the salt structure, due to stratigraphic pinchout of strata around the salt dome (Fig. 11). Furthermore, salt layers are relatively impermeable barriers that strongly play a critical role in forming structural traps (Harding and Lowell, 1979; Woodbury et al., 1980; North, 1985). Cap rock reservoirs are caused by solution and brecciation at the top of salt domes. Salt tectonics is of very great significance in many oil-bearing areas where we have thick salt deposits (Letouzey and Sherkati, 2004).

Hydrocarbon is originated from sediments in the same way as salt domes. As the salt moves upwards through overlying sediments towards the surface, hydrocarbon included in these sediments may be pooled and trapped by salt dome structures (Fig. 11). Because of the potential for petroleum production from structural and stratigraphic traps on their flanks, exploration geologists actively seek salt domes. It appears that the manifestations of hydrocarbon pools, salt diapirs and mud volcanoes are similarly found in places where thick sedimentary successions are under adequate compression due to overlying sediments or also lateral pressure mainly caused by plate convergence.

The factors decisive for reservoir pressure are fluid potential, the amount of gas dissolved in oil (gas-drive) and in the form of free gas caps overlying the oil pools, pressure from surrounding aquifer (water-drive), and the energy stored in compressed reservoir rocks. Little is known about the latter factor, which seems to be of the greatest importance. It also increases the gas-drive and the water drive. This is probably one of the reasons why the salt domes in the Zagros Mountain Ranges are more concentrated around Bandar Abbas and near the Persian Gulf, where dewatering is more functional.

The best manifestations of dewatering are the mud volcanoes which are nearly all confined to converging margins. A mixture of water, mud and gas frequently erupts from these volcanoes. The salt diapirs in the Zagros Mountain Ranges were produced in the same way (Gansser, 1960). Another place where these phenomena occur besides around the Persian Gulf is the Gulf of Mexico. More than 400 domal structures with salt in their cores are known from the northern part of the Gulf of Mexico (Jackson and Talbot, 1986). The salt rose hydrostatically or under tectonic pressure from source beds of Jurassic or older age that are now buried under many kilometers of sediment (approximately $14000 \mathrm{~m}$ ). Some of the U.S. Gulf Coast salt domes have risen through $7500 \mathrm{~m}$ or more of covering strata. They are circular or ridgelike in plan view and may be up to $10 \mathrm{~km}$ in diameter. Only five salt domes on the U.S. Gulf Coast have positive topographic relief. Although the salt penetrates Pleistocene and even Holocene sediments, deltaic progradation and fluviatile deposition have obliterated most of the salt dome relief. Avery Island, Louisiana, has a highest point of $46 \mathrm{~m}$ and forms a dome about $2.3 \mathrm{~km}$ in diameter (Standridge et al., 2005). Salt is found at a depth of about $4 \mathrm{~m}$ below its surface (Bloom, 2002).

The U.S. Gulf Coast salt domes are not ridge builders as the salt domes in the Zagros Mountain Ranges and in the Persian Gulf, but they are exactly located in the subsurface as geophysical investigations have shown (Fredrich et al., 2007).. As we know, the Gulf of Mexico is a significant oil-producing region. Unlike in the Persian Gulf, the oil seeps in the Gulf of Mexico are visible from satellite in several places. Here many barrels of brine are produced for a barrel of oil in many oil fields.

The largest hydrocarbon reservoirs around the Persian Gulf and the salt domes in the Zagros Mountain Ranges, however, are accumulated in the anticlines. Hydrocarbon deposits in exploitable amounts have not been discovered in the region. Nevertheless, indices of them are present. Borehole He E1 (Hengam) proved crude occurrence in the boundary of Ilam and Sarvak Formations during offshore drilling by the SOFIRAN (Bosak et al., 1998). Gaseous occurrences are known from numerous sites, e.g., from Qeshm Island (Pilgrim, 1908) or at Sarkhun North of Bandar Abbas (Motiei, 1990). Indices of heavy oils or asphalts were registered by previous geological mapping in Kuh-e Gavbast, Kuh-e Shu, Kuh-e Khamir, Kuh-e Anguru, Kuh-e Genow, and Kush Kuh. Sulfur springs were supposed in the past as being indications of hydrocarbons, too. Therefore, the reservoirs around the salt domes are preserved for the future. 
Fig-8. Dome-shaped swellings on elongate surface anticlines indicate the presence of many more intrusive salt masses shallow depths (Handon and Khorgo at this picture), up with $5400 \mathrm{~m}$ diagonal.

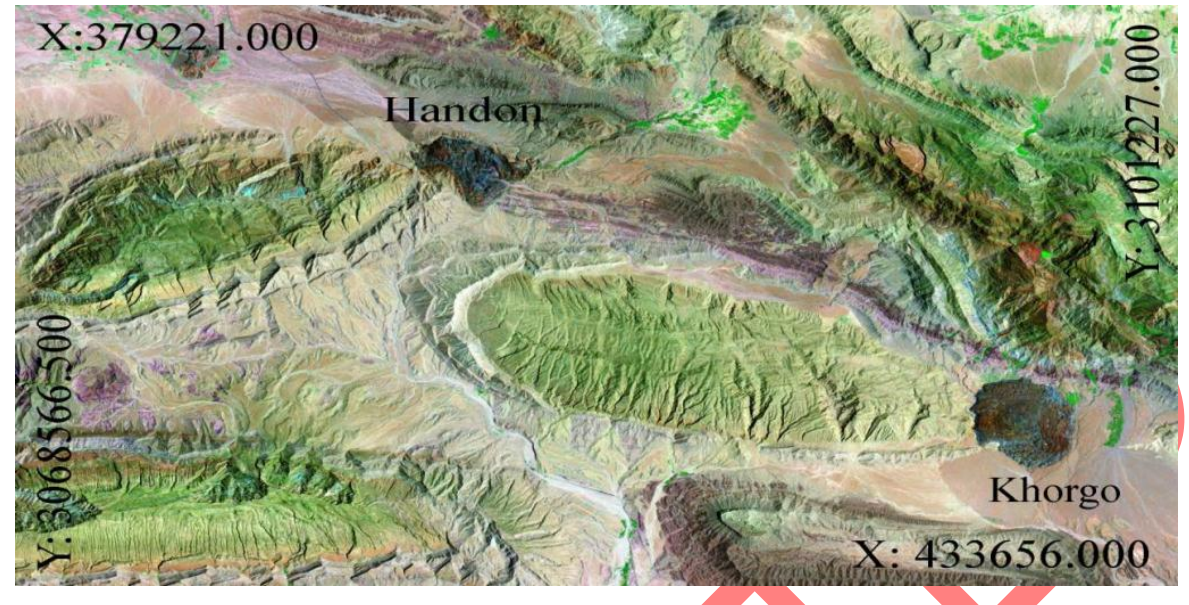

Fig-9. Such structures possibly reflect Bostrom (1985) observations of salt plugs associated with axial fold displacements. Kuhe Chiru.
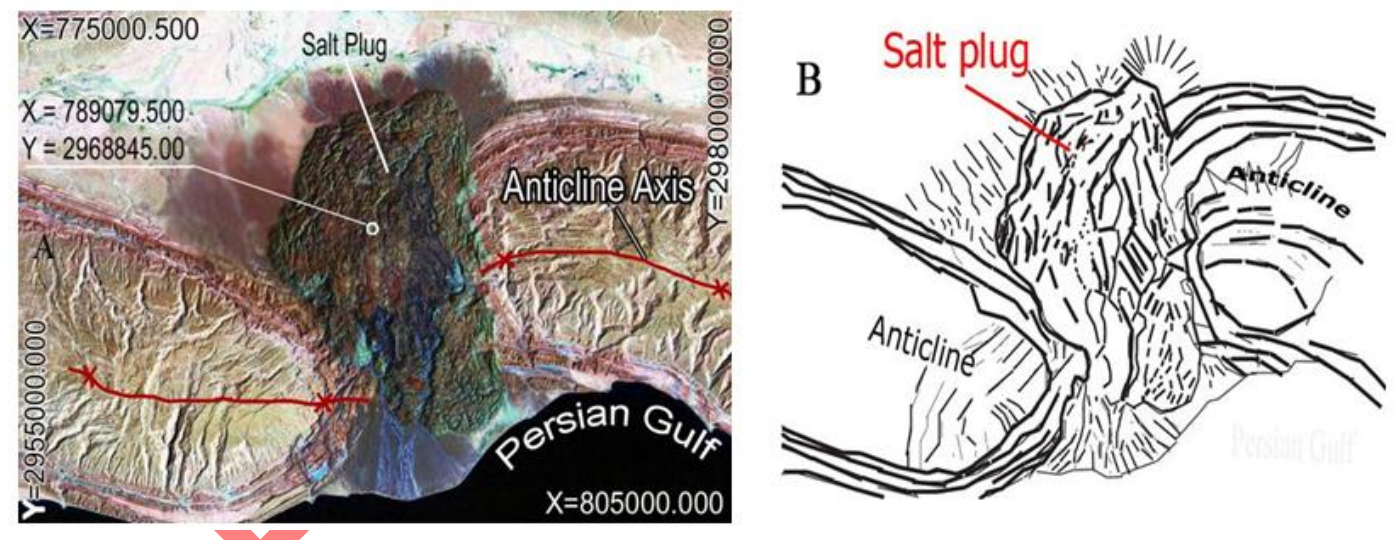

Fig-10. The presence of many more intrusive salt masses at shallow depths. Why they are not linear, but mostly equidimensional, many salt domes are exactly on the crest of anticlines.
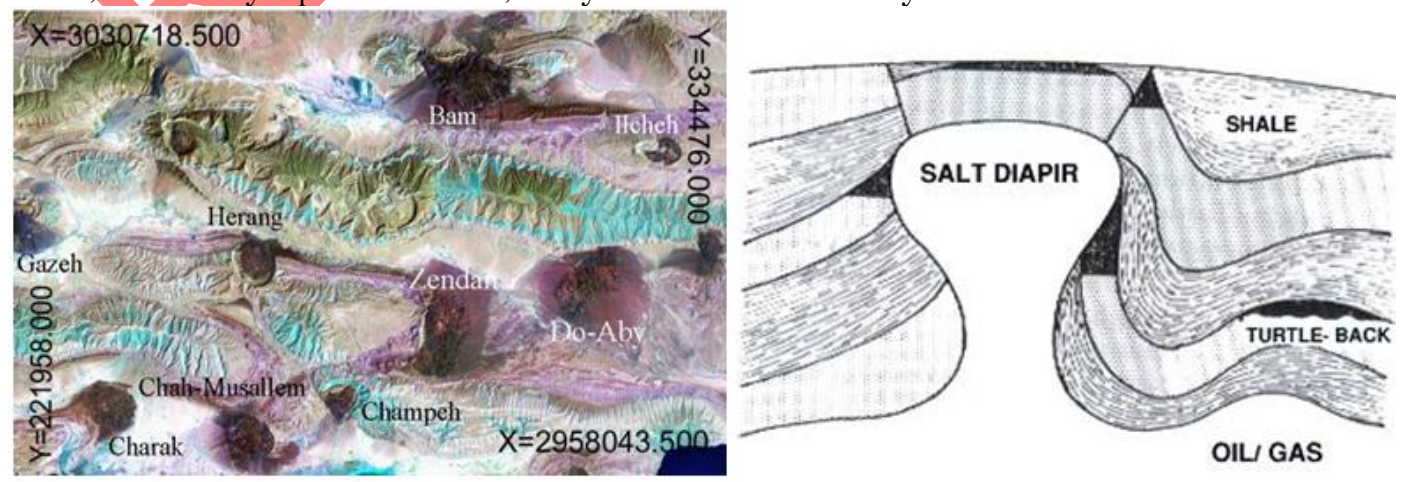


\section{DISTRIBUTION OF THE EARTHQUAKE EPICENTERS IN ADJACENT FAULTS}

Micro earthquakes represent a flow of information from the seismogenic crust up to the surface if they are detected and recorded. The distribution of the earthquake epicenters in the region has distinct trends. The diagrams of about 2000 shallow earthquake epicenters from 1900 to 2008 , as well as the special features of the more than 80 salt plugs are drawn in previous figures. The earthquakes with the known major faults exposed at the surface are shown for the salt province (Fig. 12-13). Faults identified to date in Fars and Hormuzgan are ancient and inactive. The lack of correspondence between the locations of earthquake epicenters and these faults indicates they are not responsible for earthquakes in studied region within historical times. The faults beneath the surface that generate earthquakes have yet to be positively identified. The earthquakes of lower than magnitude 5 are concentrated on salt plugs, and those of higher than magnitude 5 have a more distinct trend and confirm the strikeslip faults on geologic features (Fig. 13). The recorded earthquakes of higher than magnitude 5 are distributed in Hormuz Island, Zagros thrust, between the Genow salt plug and Namak mountain, and in northeastern of Lar salt plug. However the present seismic activity in southern Iran indicates that compression is still taking place (Nowroozi, 1971, 1972). Jacob and Quittmeyer (1979) showed present- day northward ship vectors of 4 to $5 \mathrm{~cm}$ per year along the Zagros and Makran, respectively subduction of the Arabian Platform under the Eurasian Plate. The Arabia-Eurasia convergence is accommodated differently in eastern and western Iran (Martinod et al., 2004). East of $58^{\mathrm{O}} \mathrm{E}$, most of the shortening is accommodated by the Makran subduction zone $\left(19.5 \pm 2 \mathrm{~mm} \mathrm{yr}^{-1}\right)$. West of $58^{\mathrm{O}} \mathrm{E}$, the deformation is distributed in separate fold and thrust belts (Vernant et al., 2004).

Fig-1 1. Map of earthquake epicenters recorded in Fars and the adjacent provinces between 1907 and 2008.

\section{Earthquake epicenters higher than magnitude 5}

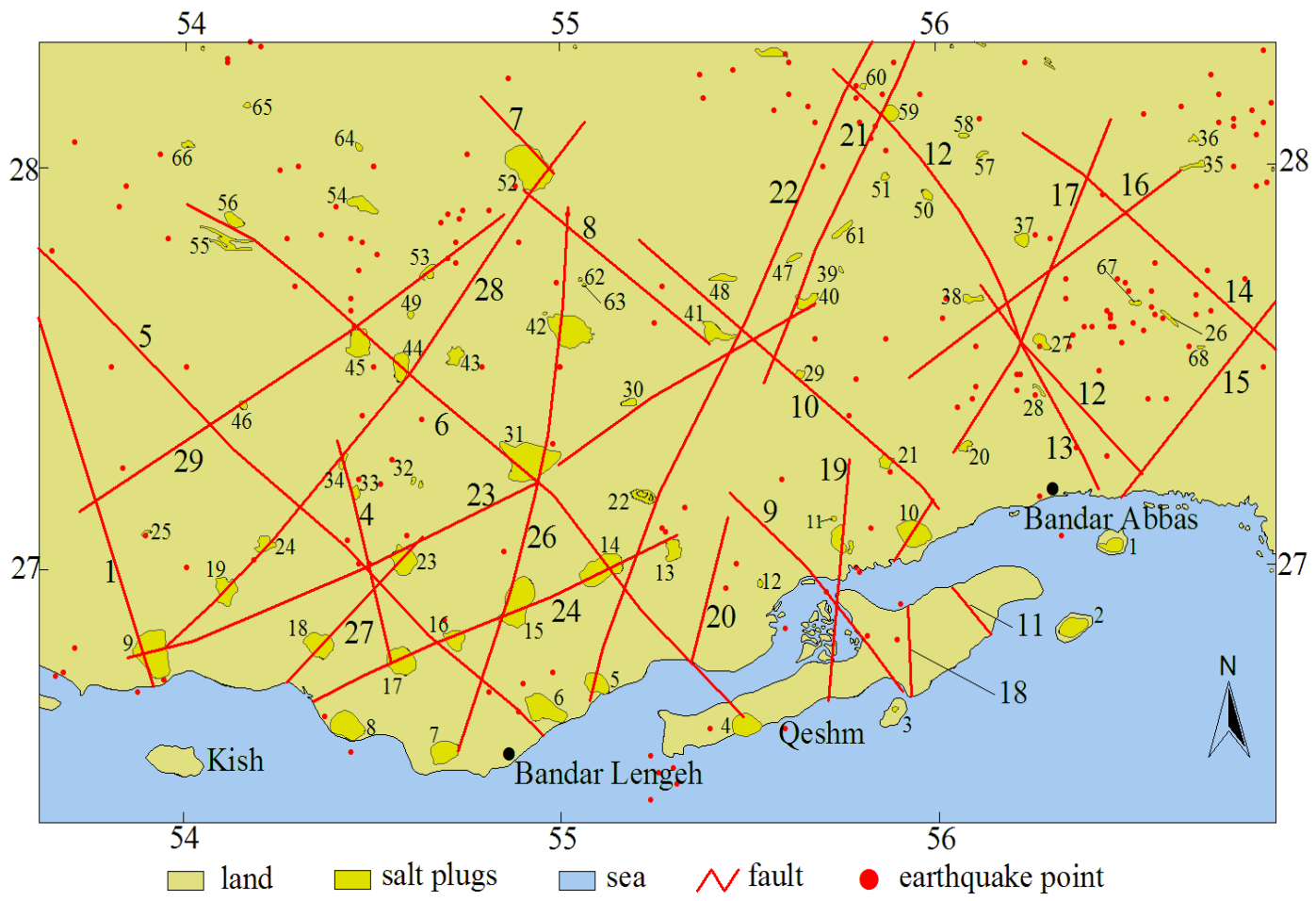




\section{CONCLUSION}

The compilation of all available data concerning salt plugs in the studied region has been obtained from field observations, image processing and literature representing the characteristics of salt plugs.

The interpretation of satellite images based on photogeology of air photos shows, that some structures have a character of regional photolineaments (especially NNWSSE and NE-SW trending. Such structures were supposed to be main fault systems of the region. Such structures commonly form broad zones of densely packed lineations.

Salt domes in the ZMR and in the Persian Gulf are not only high elevated domes, but also in many cases the salt is flowing down the flanks as "salt glacier".

Since the sedimentary environment of salt domes are potentially good resources for hydrocarbon and salt domes are good traps as well as good cop rocks, they are very

promising for hydrocarbon resources, especially in oil and gas rich area like the Persian Gulf. The displacement and bending of anticlines and synclines, the location of salt domes, and the concentration of earthquake epicenters indicate a close relationship between basement faults, salt plugs and epicenters. By means of all these features, the locations and trends of basement faults have been mapped. These basement faults could be strike-slip faults regarding the displacement of landforms (anticlines, synclines) in their paths. Also, there is a rectilinear pattern of salt plug emplacements. These implied lines of weakness are almost certainly related to basement structural trends. However, preferred orientations which correspond to the major basement lineament trends described earlier result when other lineament associated surface anomalies

are taken into consideration. Thus basement structure controls plug emplacement through its continued influence of the sedimentary cover.

Fig-12. The earthquakes of lower magnitude are concentrated on salt plugs and those of higher than magnitude 5 has a better distinct trend and confirm the strike-slip faults on geologic features.

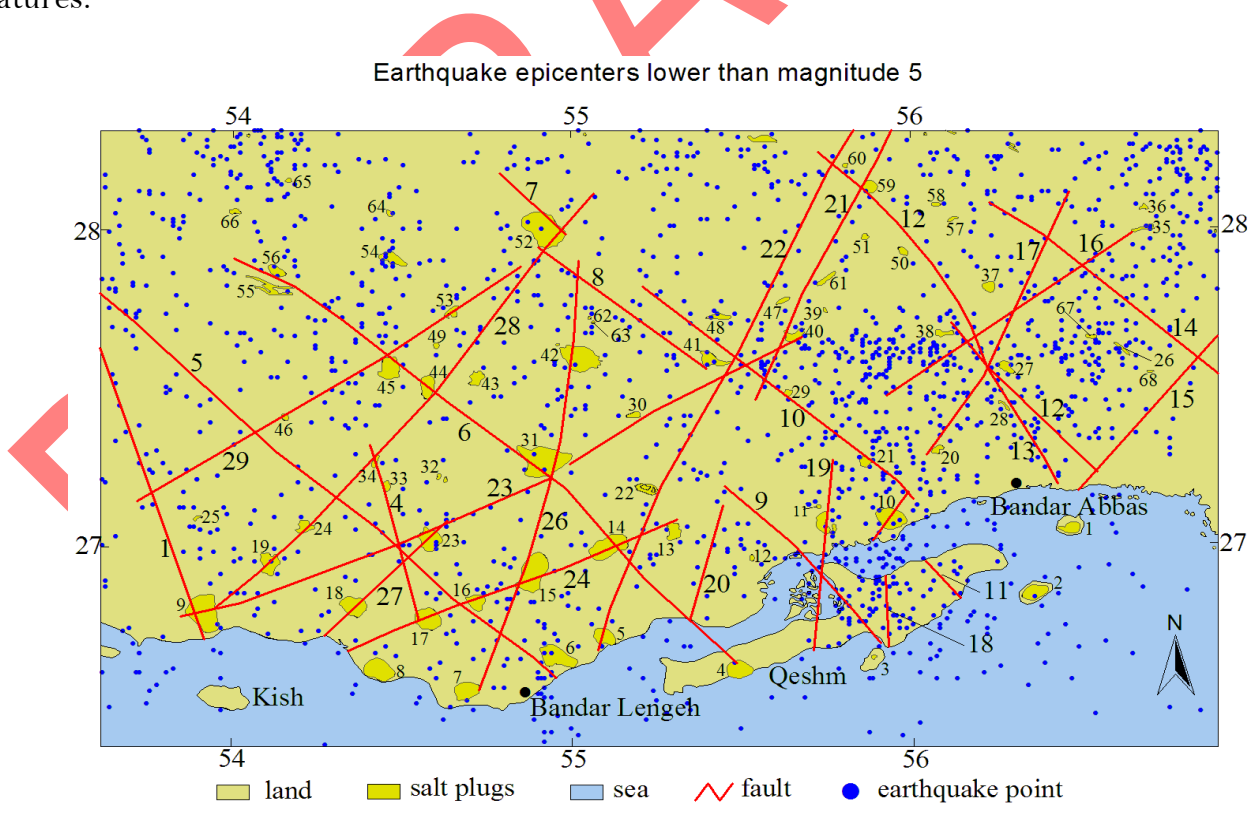

Funding: This study received no specific financial support.

Competing Interests: The author declares that there are no conflicts of interests regarding the publication of this paper. 


\section{REFERENCES}

Ala, M.A., 1974. Salt diapirism in Southern Iran, American Association Petroleum Geologists Bulletin, 58(9): $1758-1770$

Belderson, R.H., N.H. Kenyon and A.H. Stride, 1978. Local submarine salt-karst formation on the hellenic outer ridge, Eastern mediterranean. Geology, 8(6): $716-720$.

Bjørlykke, K.O., 1989. Sedimentology and petroleum geology, translated of lærebok in sedimentologi og petroleums geologi, by beverly wahl. New York: Springer-Verlag Berlin Heidelberg.

Bloom, A.L., 2002. Geomorphology, a systematic analysis of late cenozoic landforms. 3rd Edn., New Delhi: Prentice-Hall of India, Private Limited.

Böckh, H.d., G.M. Lees and F.D.S. Richardson, 1929. Contribution to the stratigraphy and tectonics of the Iranian ranges, in J. W. Gregory, editor, The structure of Asia, London, Methuen.

Bosak, P., J. Jaros, J. Spudil, P. Sulovsky and V. Vaclavek, 1998. Salt plugs in the Eastern Zagros, Iran: Results of Regional Geological Reconnaissance, GeoLines (Praha).

Bostrom, R.C., 1985. Zonal wrenching in the tethys orogeny, geodynamics research symposium. Texas: A \& M Univ.

Brink, H.J., 1986. Salzwirbelim untergrund norddeutschlands. Geowiss. in Unserer Zeit, 4(3): 81-86.

Busk, H.G. and H.T. Mayu, 1918. Some notes on the geology of the Persian oil fields, Geological Institute of Petroleum Technology, 5(3): 3-33.

Derakhshani, R. and G. Farhoudi, 2005. Existence of the oman line in the empty quarter of Saudi Arabia and its continuation in the red sea, Journal of Applied Sciences, 5(4): 745-752.

Falcon, N.L., 1967; 1969. The geology of the northeast margin of the Arabian basement shield, British Association Advanced Society, 24(5): 31-42.

Falcon, N.L., 1969. Problems of the relationship between surface structure and deep displacements illustrated by the zagros range, In: P. Kent, G. Satterthwaite and A. Spencer (Eds.), Time and Place orogeny, Geological Society of London.

Falcon, N.L., 1974. Southern Iran: Zagros mountains, in Mesozoic-Cenozoic orogenic belts: Data for orogenic studies: Alpine-Himalayan Orogens, Geological Society London, Special Publication.

Farhoudi, G., 1978. A comparison of zagros geology to Island Arcs, Journal of Geology, 86(4): 325-334.

Farhoudi, G., 1984. Some morphotectonic aspect about the frequent earthquakes in the southern part of the Zagros mountains Iran, 27th International Geological Congress Moscow.

Farhoudi, G., A. Faghih, H. Mosleh, T. Keshavarz, M.R. Heyhat and J. Rahnama-Rad, 2008. Using GIS/RS techniques to interpret different aspects of salt domes in Southern Iran, Geophysical Research Abstracts : EGU-A-06522, 10.

Farhoudi, G. and M. Ghazizadeh, 1993. Stages of karst geomorphology cycle in the Zagros mountain ranges, Iran, Proceeding of International Symposium of Water Resources in karst with special emphasis on arid and semi-arid zones, jointly organized by UNESCO and Iranian authorities, Shiraz, Iran.

Fredrich, J.T., A.F. Fossum and R.J. Hickman, 2007. Mineralogy of deepwater Gulf of Mexico salt, formations and implications for constitutive behavior, Journal of Petroleum Science and Engineering, 57(3-4): 354-374.

Friedrichs, C.T. and J.E. Perry, 2001. Tidal salt marsh morphodynamics: A synthesis. Journal of Coastal Research, 27(1): 7-37.

Fürst, M., 1990. Strike-slip faults and diapirism of the southeastern Zagros ranges. Proceeding symposium on diapirism with special reference to Iran, Geol. Survey Iran. Tehran, pp: 149-182.

Gansser, A., 1960. Über schlammvulkane und salzdome, Vierteljahrss chrift Naturforschenden Geselschaft Zurich, 105(3): 1-46.

Goudie, A.S., 1989. Salt tectonics and geomorphology, Progress in Physical Geography, SAGE Publications, 13(4): 597-605.

Harding, T.P. and J.D. Lowell, 1979. Structural styles, their plate- tectonic habitats and hydrocarbon traps in petroleum provinces. American Association Petroleum Geologists Bulletin, 63(5): 1016-1058.

Haynes, S.J. and H. McQuillan, 1974. Evolution of the Zagros suture zone, Southern Iran, Geological Society American Bulletin, 85(5): 739-744.

Humphrey, W.E., 1958. Diapirs and diapirism in Persia and North Africa, American Association petroleum Geologists Bulletin, 42(7): 1736-1744.

Jackson, M.P.A. and C.J. Talbot, 1986. External shapes, strain rates, and dynamics of salt structures. Geological Society American Bulletin, 97(3): 305-323.

Jacob, H. and K. Quittmeyer, 1979. The Makran region of Pakistan and Iran, Trench-arc system with active plate subduction. In FARAH, A., de JONGH, K.A. (editors.): Geodynamics of Pakistan. Geological Survey Pakistan. pp: 305-317.

James, G.A. and J.G. Wynd, 1965. Stratigraphic nomenclature of Iranian oil consortium agreement area, American Association Petroleum Geologists Bulletin, 49(6): 2182-2245.

Kashfi, M.S., 1976. . Plate tectonics and structural evolution of the Zagros geosyncline, southwestern Iran, Geological Society American Bulletin, 87(10): 1486-1490. 
Kent, P.E., 1958. Recent studies of south Persian salt plugs, American Association Petroleum Geologists Bulletin, 42(12): 2951-2972.

Kent, P.E., 1979. The mergent Hormuz salt plugs of Southern Iran, Jour. Petroleum Geology, 2(2): 117144.

Kent, P.E., 1979; 1986. Island salt plugs in the middle east and their tectonic implications, In dynamic geology of salt and related structures, Ed: Leiche I. \& O'Brien J. J., Academic Press, NY. pp: 3-37.

Lawrence, D.S.L., J.R.L. Allen and G.M. Havelock, 2004. Salt marsh morphodynamics: An investigation of tidal flows and marsh channel equilibrium. Journal of Coastal Research, 20(1): 301- 316.

Lees, G.M., 1927. Salzgletscher in Persien, Wien Mitteitung Geologische Gesellschaft, 20(1): 29-34.

Letouzey, J. and S. Sherkati, 2004. Salt movement, tectonic events, and structural style in the central zagros fold and thrust belt (Iran), In Salt sediments interactions and hydrocarbon prospectively, 24th Annual Gulf Coast Section SEP Foundation, Bob.

Martinod, J., A. Ashtiani, R. Bayer, F. Tavakoli and J. Chery, 2004. Present-day crustal deformation and plate kinematics in the Middle East constrained by GPS measurements' in Iran and Northern Oman, Geophysical Journal Institute, 157(3): 381- 398.

McQuillan, H., 1991. The role of basement tectonics in the control of sedimentary facies, structural patterns and salt plug emplacements in the Zagros fold belt of Southwest Iran, Journal of Southeast Asian Earth Sciences, 5(4): 453-463.

Motiei, H., 1990. The role of diapirism from the stand point of hydrocarbon reserves in South-West Iran, proceeding symposium on diapirism with special reference to Iran, 1, 138. Geol. Survey Iran. Tehran.

North, F.K., 1985. Petroleum geology. Boston: Unwin Hyman,4(2):112-116

Nowroozi, A.A., 1971. Seismo-tectonics of the Persian plateau Eastern Turkey, Caucasus, and Hindu-Kush regions, Bulletin Seismological Society America, 61(2): 317-341.

Nowroozi, A.A., 1972. Focal mechanism of earthquakes in Persia, Turkey, West Pakistan, and Afghanistan and plate tectonics of the middle east, Bulletin Seismological Society America. N.I.O.C. (National Iranian Oil Company), 1977, Tectonic map of Iran, National Iranian Oil Company, 62(7): 823-850.

Pilgrim, G.E., 1908. The geology of the Persian Gulf and the adjoining portions of Persia and Arabia, Mem. Geol. Survey India, 34(4): 1-177.

Pilgrim, G.E., 1922. The Sculpture deposits of southern Persia, India Geol. Survey Research, 53(3): 343358.

Pilgrim, G.E., 1924. The geology of parts of the Persian provinces of fars, Kerman and Laristan, Mem. Geol. Survey India, 48(1): 1-118.

Player, R.A., 1967. A note on the Fars salt plugs, N.I. O. C., Private Report.

Player, R.A., 1969. Salt plug study, N. I. O. C., Report, 1146.

Rabinowitz, P.D., M.F. Coffin and D. Falvey, 1982. Salt diapirs bordering the continental margin of northern Kenya and southern Somalia, Science, $21(5)$ : $663-665$.

Rahnama-Rad, J., R. Derakhshani, G. Farhoudi and M. Ghorbani, 2008. Basement faults und salt plug emplacement in the Arabian platform in southern Iran, Journal of Applied Science, 8(18): 32353241.

Richardson, R.K., 1926. Die geologie und die salzdome imsudwestlichen teil des persischen golfes, verhandlung naturhistorische medizin verein heidelberg (NF), Nummer 15, 51 Seite.

Richardson, R.K., 1928. Weitere bemerkungen zu der geologie und den salzaufbruchen am persischen golf, centralblat mineralogie, Geologie u. Paläontologie Abteitung B: 45-49.

Ross, D.A., R.B. Whitmarsh, S.A. Ali, J.E. Boudreaux, R. Coleman, R.L. Fleisher, R. Girdler, F. Manheim, A. Matter, C. Nigrini, P. Stoffers and P.R. Supko, 1973. Red sea drillings. Science, 17(3): 377-380.

Schoenherr, J.U., L.K. Janos, A. Peter, R. Littke, Z. Schléder, J.-M. Larroque, M.J. Newall, N. Al-Abry, H.A. Al-Siyabi and Z. Rawahi, 2007. Limits to the sealing capacity of rock salt: A case study of the infraCambrian Ara Salt from the South Oman salt basin, American Association Petroleum Geologists Bulletin, 91(11): 1541-1557.

Seni, S.J. and M.P.A. Jackson, 1983a. Evolution of salt structures, east texas diapir province; Part 1, Sedimentary Record of Halokinesis, 67(4): 1219-1244.

Seni, S.J. and M.P.A. Jackson, 1983b. Evolution of salt structures, east texas diapir province; part 2, patterns and rates of halokinesis. American Association Petroleum Geologists Bulletin, 67(5): 1245 - 1274.

Standridge, D., C. Bishop and L. Serpa, 2005. A high- resolution seismic survey to image the top of salt at Avery Island, Louisiana, SEG( Society of Exploration Geophysicists) Technical Program Expanded Abstracts: 1160-1163.

Stöcklin, J. and M.H. Nabavi, 1975. Tectonic map of Iran, 1: 2500000, Geological Society Iran.

Talbot, C.J. and M. Alavi, 1996. The post of a future syntaxis across the Zagross, in Alsop, G. I., Blunell, D.J. \& Davison, J. (eds), salt tectonics: Geological Society London, Special Publication, 100(1): 89-109. 
Talbot, C.J. and M.P.A. Jackson, 1987. Internal kinematics of salt diapirs. American Association Petroleum Geologists Bulletin, 71(5): 1068-1093.

Talbot, C.J. and E.A. Rogers, 1980. Seasonal movements in a salt glacier in Iran, Science, 20(4): 395-397.

Tchalenko, J.S. and J. Braud, 1974. Seismicity and structure of the Zagros (Iran), the main recent fault between 330 and 350 N, London Philos. Trans., Serie A., 27(7): 1-25.

Trusheim, F., 1960. Mechanism of salt migration in northern Germany, American Association Petroleum Geologists Bulletin, 44(5): 1519-1540.

Vernant, P., F. Nilforoushan, D. Hatzfeld, M.R. Abbassi, C. Vigny, F. Masson, H. Nankali, J. Martinod, A. Ashtiani, R. Bayer, F. Tavakoli and J. Chéry, 2004. Present- day crustal deformation and plate kinematics in the middle east constrained by GPS measurements in Iran and northern Oman, Geophysical Journal International, 15(3): 381-398.

Woodbury, H.O., I.B. Murray and R.E. Osborne, 1980. Diapirs and their relation to hydrocarbon accumulation, in: A. D. Miall, (ed)., Fact and principles of world petroleum occurrence: Calgary, Canadian Society of Petroleum Geologists.

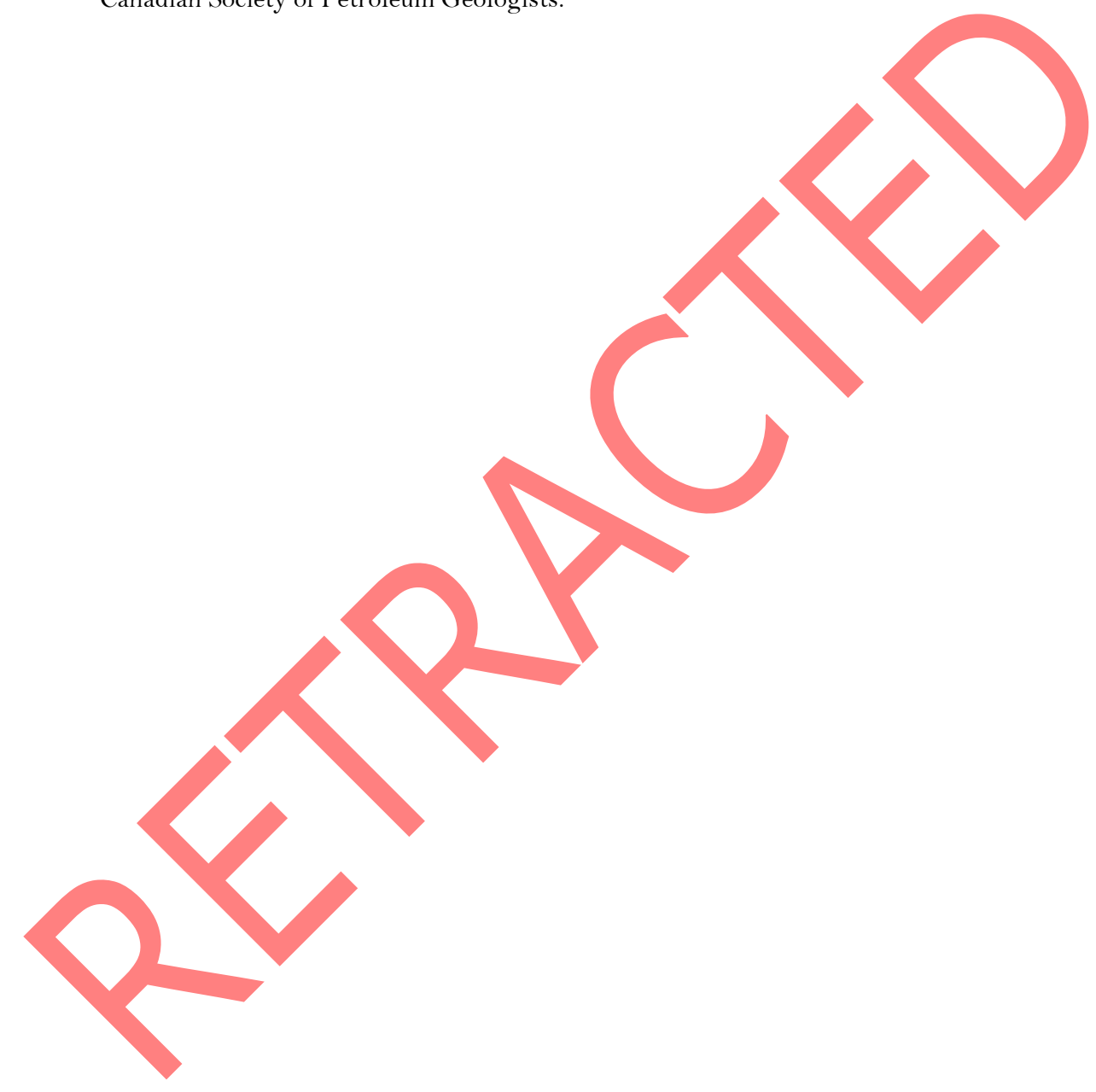

Views and opinions expressed in this article are the views and opinions of the author(s), International Journal of Geography and Geology shall not be responsible or answerable for any loss, damage or liability etc. caused in relation to/arising out of the use of the content. 